\title{
Effect of Irrigation Regime and Nitrogen Fertilization Levels on Sugarcane Yield and Its Components
}

\author{
Shahrzad M.M. Neana ${ }^{1}$ and Kamla A.E. Abd El Hak ${ }^{2}$
}

\begin{abstract}
Two field experiments were carried out at the Research Experimental Farm of Sabahia Agricultural Research Station in Alexandria during the two successive growing seasons of 2011/ 12 and 2012/ 13. G2006-77 sugarcane variety (Saccharum officinarum L) was cultivated to investigate the effect of irrigation regime and nitrogen fertilizer level and their interaction on sugarcane yield and its components. Main plots were represented by three irrigation regime:1- (large interval) 18 irrigations/ year was given to first treatment irrigation at (15 days interval in Summer, 20 days interval in Spring and Autumn and 30 days interval in Winter seasons), 2(middle interval) 25 irrigations / year was given to second treatment irrigation at (10 days interval in Summer, 15 days interval in Spring and Autumn and 21 days interval in Winter seasons) and 3- (short interval) 32 irrigations / year was given to third treatment irrigation at $(7$ days interval in Summer, 13 days interval in Spring and Autumn and 15 days interval in Winter seasons,). The sub plots were used for the three nitrogen levels $(140,200$ and $260 \mathrm{~kg} \mathrm{~N} / \mathrm{Fed}$ ). The results indicated that:
\end{abstract}

The second regime middle irrigation intervals was insignificantly increased stalk length, stalk diameter, stalk yield, sugar yields, T.S.S (\%), sucrose (\%) and purity (\%) compare with the first and third regime through the two successive seasons.

Increasing applied N levels from 140 up to $200 \mathrm{Kg} \mathrm{N}$ /fed. significantly increased stalk length, stalk diameter, stalk yield, sugar yields T.S.S (\%), sucrose (\%) and purity (\%).

The interaction between irrigation intervals and nitrogen levels on the studied traits were not significant except sucrose (\%) in the two seasons.

Keywords: Sugarcane (Saccharum officinarum L), irrigation intervals, nitrogen fertilizer rate, stalk length, stalk diameter, stalk yield, sugar yield, T.S.S\%, sucrose \% and purity\%.

\section{INTRODUCTION}

Sugarcane (Saccharum officinarum L) requires substantial inputs of both water and nitrogen to achieve maximum yields. Regional water supplies are often limited. Compared to other crops, little is known about how far water can be stretched in sugarcane without affecting sugar yield. In particular, there is little information on the response of important yield forming processes to soil water deficits. Irrigation can increase sugarcane yield and it increases the sustainability of crop production Gary et al., (2000)

Water present about $75 \%$ of sugarcane stalks and has a vital role in absorption and transporting of mineral nutrients from soil to plant roots and shoots. Yadav et al.,(1990). Availability of water is an important factor causing variation in sugarcane yield and juice quality Wiedenfeld and Enciso (2008) found that increasing irrigation levels increased sugar and sugarcane yields and sucrose content. Ali (1996) mentioned that irrigated sugarcane at 15 or 45 available soil moisture and reported that juice quality was unaffected by irrigation treatments. El- Shafai (1996) cleared that applying irrigation at shorter intervals increased stalk diameter and applying 26 irrigations/ season produced the highest sugarcane yield without significant differences with the others 20 and 17 irrigations/ season. Gomaa (2000) irrigated sugarcane every 14, 21, 28,35 and 42 days. The results showed significant differences among the sugarcane varieties (G.T.54-9, G.85-37, G.84-47 and F.153) for average stalk height and sucrose percentage which was increased as irrigation intervals decreased in both seasons. On the contrary, sugar recovery percentage decreased as irrigation intervals decreased. Increasing irrigation intervals caused a reduction in sugarcane yield/fed., but this reduction was not significant while increasing irrigation intervals significantly decreased sugar yield/fed. According to Azzazy et al., (2000) water is the key to sugarcane growth, development and subsequent conversion of recoverable sugar to sucrose. Immbaby (2003) and Maher (2003) said that application of 22 or 19 irrigations / season resulted the highest cane and sugar yield. El-Geddawy et al., (2004) showed that sugar recovery $\%$, number of millable cane and sugar yields were insignificantly affected by the applied irrigation regimes. Bekheet (2006) concluded that stalk length, stalk diameter and cane yield/fed were significantly increased by decreasing irrigation intervals from 20 to 12 days. in both seasons. Applying irrigation water every 12 or 16 days attained significant increase in the number of millable cane/fed. and sugar yield/fed.

\footnotetext{
${ }^{1}$ Sabahia Research Station- Sugar Crops Institute -

Agricultural Research Center.Giza

${ }^{2}$ Sabahia Research Station- Regional Research Station-

Agricultural Research Center Giza

Received November 9, 2014, Accepted December 16, 2014
} 
However both of sucrose and sugar recovery percentages were negatively and significantly affected by increasing the periods between irrigation. InmanBamber and Smith (2005) Indicated that responses to increased irrigation may not be as large as generally believed. It is remarkable that yield of cane, sucrose and biomass were not affected by irrigation varying from 349 to $672 \mathrm{~mm}$ in a dry year Yahaya et al., (2010) irrigation scheduled at 1-, 2-, 3-, and 4- week intervals. The yield and yield components were highest with irrigation at 1-week interval. Barbosa et al., (2014) Water balance with values less than $-13 \mathrm{~mm}$ cause a significant decrease in the final population of plants, regardless of the variety, and values below $-35 \mathrm{~mm}$, leads to the death of all plants.

Nitrogen is the most essential element having direct effect on cane growth, sugarcane yield, and juice quality. Studies have established that $\mathrm{N}$ increase the quantity of green tops, yield components and yield of cane and sugar Azzazy and El-Geddawy, (2003), ElGeddawy et al., (2003), Nassar et al., (2005) and ElGeddawy et al., (2005) Similarly, Yousef et al., (2000) reported that nitrogen has significant influence on cane growth, yield, quality and recoverable sugar. However, nitrogen application at high rates exceeding sugarcane plant utilization has adverse effect on cane quality. However Qureshi et al., (2001) reported that the amount of water utilized by cane plant has a linear relationship to total dry matter produced. A favorable soil water condition during cane growth also has a significant effect on the yield and quality response of sugarcane to nitrogen fertilization Bhatti et al., (1986). According to Taha, et al., (2003), meeting the nutrient and water requirements of sugarcane effectively makes the crop flourish and yield profitably.

More information is regime on the influence of nitrogen fertilizer levels on sugarcane yield and quality under various irrigation regimes. This knowledge is required to develop better fertilizer and irrigation practice in the crop. The objectives of this research were to determine the effect of nitrogen fertilizer levels and irrigation regime on sugar yield, yield components and sugar quality of sugarcane.

\section{MATERIALIS AND METHODS}

Two field experiments were conducted in the Research Experimental Farm of Sabahia Agricultural Research in Alexandria Station during the successive growing seasons of 2011/ 12 and 2012/ 13. G2006-77 sugarcane variety (Saccharum officinarum L) was cultivated to study the effect of irrigation regimes and nitrogen fertilizer levels and their interactions on sugar yield and its components of sugarcane.
27 Plots $\left(15 \mathrm{~m}^{2}\right)$ for each treatments, were used to carry out the experiment with three replicates in a split plot design. Main plots were used for the irrigation regime: 1- (large intervals) 18 irrigations/ year were given to first treatment irrigation at ( 15 days intervals in Summer, 20 days intervals in Spring and Autumn and 30 days intervals in Winter seasons), 2- (middle intervals) 25 irrigations / year were given to second treatment irrigation at (10 days intervals in Summer, 15 days intervals in Spring and Autumn and 21 days intervals in Winter seasons) and 3- (short intervals) 32 irrigations / year were given to Third treatment irrigation at ( 7 days intervals in Summer, 13 days intervals in Spring and Autumn and 15 days intervals in Winter seasons).

Irrigation was conducted through a water meter of 0.1 cubic meter accuracy used to be tightly hooked where the wide inlet towards the main permanent canal and the outlet towards the lateral temporary field canal of the irrigated plots. Each plot was irrigated individually by allowing water to flow over the plot through an opening in the temporary field canal. After a complete saturation of the plot, the opening whole is closed and water allowed to flow over another plot. This plots were surrounded with borders of 2 meters width to prevent the seepage of water to other plots.

The sub plots for the nitrogen fertilizer levels (140, 200 and $260 \mathrm{Kg} \mathrm{N} /$ fed.) as ammonium nitrate $(33.5 \% \mathrm{~N})$. were added in two equal doses the $1^{\text {st }}$ one after 60 days from planting and the $2^{\text {nd }}$ after 30 days later. Before planting soil samples were randomly taken from the experimental site at a depth of 0 to $30 \mathrm{~cm}$ and prepared for chemical analysis (Table 1) according to standard methods edited by to Ankerman and large (1974). G2006-77 sugarcane variety was obtained from Sugar Crops Research Institute, Agricultural Research Center, Giza. Stem cutting were hand planted in October in the two seasons. All the agronomic practices for growing sugarcane were carried out as recommended by the Sugar Crops Research Institute. At harvested five plants from each sub-plot were taken at random to determine the following data:

1- Stalk length $(\mathrm{cm})$ was measured from soil surface to the top point of visible dewlap.

2- Stalk diameter $(\mathrm{cm})$ was measured at the middle part of stalk.

3- Stalk yield (ton/fed) cane stalks of each plot were off cleaned from trash, weighed and cane yield was calculated.

4- Total soluble solids (T.S.S.\%) was measured by hand refractometer according to the methods outlined in the A.O.A.C.(1985). 
Table 1. Some chemical properties of soil at the experimental site:

\begin{tabular}{|c|c|c|c|c|c|c|c|c|c|c|c|}
\hline \multirow[t]{2}{*}{ Season } & \multirow{2}{*}{$\frac{E C}{d S ~ m^{-1}}$} & \multirow[t]{2}{*}{ pH } & \multicolumn{4}{|c|}{ Cations (meq/L) } & \multicolumn{4}{|c|}{ Anions (meq/L) } & \multirow{2}{*}{$\begin{array}{c}\text { mg/ kg soil } \\
\mathrm{N}\end{array}$} \\
\hline & & & $\mathrm{Ca}^{2+}$ & $\mathrm{Mg}^{2+}$ & $\mathrm{Na}^{+}$ & $\mathbf{K}^{+}$ & $\mathrm{HCO}_{3}^{-}$ & $\mathrm{CO}_{3}{ }^{2-}$ & $\mathrm{Cl}^{-}$ & $\mathrm{SO}_{4}{ }^{2-}$ & \\
\hline $1^{\mathrm{st}}$ & 2.7 & 8.0 & 7.5 & 6.9 & 10.2 & 1.2 & 1.5 & 0.0 & 24.6 & 1.6 & 11.0 \\
\hline $2^{\text {nd }}$ & 2.9 & 8.1 & 8.0 & 6.9 & 12.0 & 1.1 & 1.4 & 0.1 & 25.5 & 1.5 & 11.3 \\
\hline
\end{tabular}

5- Sucrose (\%) was determined by Digital Automatic Polarimeter A.O.A.C.(1985).

6- Purity (\%) was calculated using the following formula according to Singh and Singh (1998)

7- Juice purity $(\%)=\operatorname{sucrose}(\%)$, / T.S.S.(\%) X100.

8- Sugar yield (ton /fed) was determined by multiply yield of stalks X sucrose $\%$.

The obtained data of the two investigated seasons were computed and statistically analyzed for testing the significance of the studied factors and their interactions by L.S.D. test according to Steel and Torrie (1981).

\section{RESULTS AND DISCUSSION}

\section{1- Yield and yield components:}

The effect of irrigation and nitrogen levels on stalk length, stalk diameter, stalk yield and sugar yield through the two successive seasons 2011/12 and 2012/13 were highly significant as shown in (Table 2).

Increases in irrigation regime consistently resulted in a significant decrease in stalk length. Application of nitrogen at 200 and $260 \mathrm{~kg} /$ fed resulted in significantly higher cane length compared to 140 and $200 \mathrm{~kg}$. N/fed that are statistically comparable these results are similar to those Gomaa (2000), and Bekheet (2006).

Data given in (Table 2), showed that the irrigation regime had a significant effect on stalk diameter, in both seasons .Applying irrigation water at intervals of the second regime at (10 days intervals in Summer, 15 days intervals in Spring and Autumn and 21 days intervals in Winter seasons) resulted in the thickest stalks compared with other regimes. These results matched these reported by El- Shafai (1996), Gomaa (2000) and Bekheet (2006).

The results in (Table 2) showed that nitrogen fertilizer levels significantly effect on stalk diameter, in both seasons. Increasing the applied $\mathrm{N}$ doses from 140 up to $260 \mathrm{Kg}$. $\mathrm{N} / \mathrm{fed}$. increasing stalk diameter, gradually. These results in agreement with Nassar et al.,(2005).

The results in (Table 2) showed that the middle irrigation regime of the second regime significantly increased stalk yield compared with the first and third regimes through the two successive seasons 2011/12 and 2012/13. Increasing $\mathrm{N}$ level from 140 up to $200 \mathrm{Kg}$ $\mathrm{N} /$ fed. increasing stalk yield (39.34 and 38.87 ton/ fed.) in the first and second seasons, respectively.

Table 2. Means of stalk length $(\mathrm{cm})$, stalk diameter $(\mathrm{cm}$.$) , stalk yield(ton/ fed), and sugar$ yields(ton /fed) as affected by irrigation regime and nitrogen levels and their interactions during 2011/12, 2012/13 seasons

\begin{tabular}{|c|c|c|c|c|c|c|c|c|}
\hline \multirow{2}{*}{$\begin{array}{l}\text { Factors } \\
\text { Seasons } \\
\end{array}$} & \multicolumn{2}{|c|}{$\begin{array}{l}\text { Stalk length } \\
(\mathrm{cm})\end{array}$} & \multicolumn{2}{|c|}{$\begin{array}{c}\text { Stalk diameter } \\
(\mathbf{c m})\end{array}$} & \multicolumn{2}{|c|}{$\begin{array}{l}\text { Stalk yield } \\
\text { (ton /fed) }\end{array}$} & \multicolumn{2}{|c|}{$\begin{array}{c}\text { Sugar yield } \\
\text { (ton /fed) }\end{array}$} \\
\hline & $1^{\text {st }}$ & $2^{\text {nd }}$ & $1^{\text {st }}$ & $2^{\text {nd }}$ & $1^{\text {st }}$ & $2^{\text {nd }}$ & $1^{\text {st }}$ & $2^{\text {nd }}$ \\
\hline \multicolumn{9}{|c|}{ A- Irrigation regime / year } \\
\hline 18 irrig. large & $189.30^{\mathrm{a}}$ & $198.20^{b}$ & $2.43^{\mathrm{b}}$ & $2.64^{\mathrm{b}}$ & $30.69^{b}$ & $32.74^{\mathrm{b}}$ & $4.70^{\mathrm{b}}$ & $4.50^{b}$ \\
\hline 25 irrig. middle & $201.70^{\mathrm{a}}$ & $210.70^{\mathrm{a}}$ & $2.51^{\mathrm{a}}$ & $2.86^{\mathrm{a}}$ & $33.96^{\mathrm{a}}$ & $34.92^{\mathrm{a}}$ & $4.98^{\mathrm{a}}$ & $4.92^{a}$ \\
\hline 32 irrig. short & $172.70^{b}$ & $186.20^{\mathrm{c}}$ & $2.10^{\mathrm{c}}$ & $2.54^{\mathrm{c}}$ & $28.49^{\mathrm{c}}$ & $30.92^{\mathrm{c}}$ & $4.25^{\mathrm{c}}$ & $4.16^{\mathrm{c}}$ \\
\hline LSD.05 & 12.56 & 3.46 & 0.05 & 0.08 & 1.05 & 1.05 & 0.21 & 0.14 \\
\hline \multicolumn{9}{|c|}{ B- Nitrogen levels Kg /fed. } \\
\hline 140 & $181.20^{b}$ & $164.80^{c}$ & $2.37^{\mathrm{b}}$ & $2.32^{\mathrm{c}}$ & $22.53^{c}$ & $27.42^{\mathrm{c}}$ & $3.52^{c}$ & $3.51^{\mathrm{c}}$ \\
\hline 200 & $207.50^{\mathrm{a}}$ & $192.40^{b}$ & $2.51^{\mathrm{b}}$ & $2.71^{\mathrm{b}}$ & $39.34^{\mathrm{a}}$ & $38.87^{\mathrm{a}}$ & $5.89^{\mathrm{a}}$ & $5.63^{a}$ \\
\hline 260 & $225.10^{\mathrm{a}}$ & $238.10^{\mathrm{a}}$ & $2.50^{\mathrm{a}}$ & $3.03^{\mathrm{a}}$ & $31.26^{\mathrm{b}}$ & $32.29^{b}$ & $4.52^{b}$ & $4.46^{b}$ \\
\hline LSD.05 & 20.7 & 7.3 & 0.03 & 0.07 & 0.94 & 0.82 & 0.94 & 0.29 \\
\hline \multicolumn{9}{|c|}{ C-Interactions } \\
\hline$A \times B$ & ns & ns & ns & ns & ns & ns & ns & ns \\
\hline
\end{tabular}

*LSD $=$ Least significant difference

*,** and NS, significant at $0.05,0.01$ probability level and non-significant, respectively 

These findings may be due to the increase in the vigorous characteristics of plant grown which let to more competition between them consequently increased plant mortality It could be concluded that the 200 $\mathrm{Kg} / \mathrm{fed}$. $\mathrm{N}$ level was quite satisfactory to produce the maximum stalk yield in both seasons. The results are in agreement with those reported by Azzazy and ElGeddawy, (2003) and El-Geddawy et al., (2005).

The results in (Table 2) obtained that the differences between the studied irrigation regime had significant effect on sugar yields in both seasons. The second irrigation regime produced the highest sugar yields which were (4.98 and $4.92 \mathrm{ton} / \mathrm{fed})$ in the $1^{\text {st }}$ and $2^{\text {nd }}$ seasons, respectively. Concerning fertilization treatments, the obtained results showed that sugar yields were statistically affected by fertilization treatments. The highest values of sugar yield (5.89 and 5.63 ton/ fed) produced from the application of nitrogen fertilizer level $(200 \mathrm{kgN} / \mathrm{fed})$ during the two growing seasons, respectively. The results are in the line with that reported by El-Geddawy et al., (2005)

The interactions between irrigation regimes and nitrogen levels effect on the studied treats did not reach the significance level in the two seasons (Table 2).

\section{2- Juice quality}

Juice quality measurements of sugarcane in terms of as affected by irrigation regime and nitrogen levels as well as their interactions are shown in (Table 3 ).

The effect of irrigation regimes and nitrogen levels on the quality of cane juice, as expressed by T.S.S (\%), sucrose $(\%)$ and purity (\%) contents of the cane juice are presented in (Table 3). The influence of irrigation regime on cane quality characters were highly significant in the two seasons. Although increase in irrigation regime appears to reduce T.S.S (\%), in the two seasons, the difference in T.S.S $(\%)$, due to $1^{\text {st }}$ and $2^{\text {nd }}$ irrigation regime were statistically significant. The second irrigation regime produced higher T.S.S(\%), which were $(19.94$ and $19.53 \%)$ in the $1^{\text {st }}$ and $2^{\text {nd }}$ seasons, respectively. The data also showed that T.S.S( $\%$ ),sucrose(\%) and purity (\%) diminish in a linear fashion with increasing irrigation regime interval, the maximum reduction being at the longest interval 32 irrigations/year in both seasons. The result is in accordance with Gomaa (2000)

The results showed that nitrogen levels had significant effect on all the cane quality attributes in 2011/12 and 2012/13 seasons where the T.S.S (\%), sucrose (\%) and purity (\%) recorded at $140 \mathrm{~kg} \mathrm{~N} /$ fed. was statistically at par with that at $260 \mathrm{~kg} / \mathrm{fed}$. with regard to T.S.S (\%), Generally application of $200 \mathrm{~kg} \mathrm{~N}$ /fed seems to have caused greater significant increacing in quality compared to lower and higher levels. The result is in the line with that reported by Bahrani et al., (2009).

The interaction between irrigation regimes and nitrogen levels effects on all juice quality parameters were not significant in T.S.S (\%) and purity (\%) among the two seasons. Sucrose (\%) was significantly influenced by the interaction between irrigation regime and nitrogen levels in both seasons.

Table (4) revealed that statistically significant of interaction differences between irrigation regimes and nitrogen levels for, sucrose (\%) in both seasons 2011/ $12,2012 / 13$.

Table 3. Means of T.S.S( $\%)$, sucrose(\%) and purity(\%) as affected by irrigation regime and nitrogen levels and their interactions during 2011/12 and 2012/13 seasons

\begin{tabular}{|c|c|c|c|c|c|c|}
\hline \multirow{2}{*}{$\begin{array}{l}\text { Factors } \\
\text { Seasons }\end{array}$} & \multicolumn{2}{|c|}{ T.S.S.\% } & \multicolumn{2}{|c|}{ Sucrose \% } & \multicolumn{2}{|c|}{ Purity \% } \\
\hline & $1^{\text {st }}$ & $2^{\text {nd }}$ & $\mathbf{1}^{\text {st }}$ & $2^{\text {nd }}$ & $1^{\text {st }}$ & $2^{\text {nd }}$ \\
\hline \multicolumn{7}{|c|}{ A- Irrigation regime / year } \\
\hline 18 irrig. large & $19.49^{b}$ & $19.03^{b}$ & $13.88^{\mathrm{b}}$ & $14.38^{b}$ & $72.5^{b}$ & $73.92^{b}$ \\
\hline 25 irrig.middle & $19.94^{\mathrm{a}}$ & $19.53^{\mathrm{a}}$ & $14.34 \mathrm{a}$ & $14.71^{\mathrm{a}}$ & $75.3^{\mathrm{a}}$ & $77.69^{\mathrm{a}}$ \\
\hline 32 irrig. short & $19.09^{\mathrm{c}}$ & $18.72^{\mathrm{c}}$ & $13.61^{\mathrm{c}}$ & $13.98^{\mathrm{c}}$ & $68.5^{c}$ & $70.40^{\mathrm{c}}$ \\
\hline LSD.05 & 0.12 & 0.16 & 0.13 & 0.14 & 1.05 & 1.56 \\
\hline \multicolumn{7}{|c|}{ B- Nitrogen levels Kg /fed. } \\
\hline 140 & $18.85^{\mathrm{b}}$ & $18.05^{\mathrm{b}}$ & $13.97^{b}$ & $14.56^{b}$ & $70.52^{b}$ & $73.92^{b}$ \\
\hline 200 & $20.76^{\mathrm{a}}$ & $20.41^{\mathrm{a}}$ & $14.95^{\mathrm{a}}$ & $15.41^{\mathrm{a}}$ & $81.55^{\mathrm{a}}$ & $82.36^{\mathrm{a}}$ \\
\hline 260 & $18.93^{\mathrm{b}}$ & $18.81^{b}$ & $12.90^{\mathrm{c}}$ & $13.11^{\mathrm{c}}$ & $64.35^{\mathrm{c}}$ & $65.72^{\mathrm{c}}$ \\
\hline LSD.05 & 0.21 & 0.23 & 0.20 & 0.22 & 0.73 & 1.46 \\
\hline \multicolumn{7}{|c|}{ C-Interactions } \\
\hline $\mathbf{A} \times \mathbf{B}$ & ns & ns & $*$ & $* *$ & ns & \\
\hline
\end{tabular}

*LSD $=$ Least significant difference.

$*, * *$ and NS, significant at $0.05,0.01$ probability level and non-significant, respectively. 
Table 4. The interaction between irrigation regime and nitrogen levels on Sucrose\% of sugarcane plant during 2011/12, 2012/13 seasons.

\begin{tabular}{llcccccc}
\hline & Seasons & \multicolumn{3}{c}{$\mathbf{2 0 1 1 / 1 2}$} & \multicolumn{3}{c}{$\mathbf{2 0 1 2 / 1 3}$} \\
\hline N. (kg/fed) & Irrigation regime / year & $\begin{array}{c}\mathbf{1 8} \\
\text { irrig. }\end{array}$ & $\begin{array}{c}\mathbf{2 5} \\
\text { irrig. }\end{array}$ & $\begin{array}{c}\mathbf{3 2} \\
\text { irrig. }\end{array}$ & $\begin{array}{c}\mathbf{1 8} \\
\text { irrig. }\end{array}$ & $\begin{array}{c}\mathbf{2 5} \\
\text { irrig. }\end{array}$ & $\begin{array}{c}\mathbf{3 2} \\
\text { irrig. }\end{array}$ \\
\hline 140 & 12.58 & 14.51 & 13.75 & 12.57 & 15.19 & 14.19 \\
\hline 200 & 12.78 & 15.38 & 13.95 & 13.06 & 15.56 & 14.63 \\
\hline 260 & 13.36 & 14.90 & 14.22 & 13.69 & 15.48 & 14.87 \\
\hline LSD.05 & \multicolumn{3}{c}{0.14} & & & 0.16 & \\
\hline
\end{tabular}

The highest value of sucrose percentage (16.07and $17.20 \%$ ) were recorded from application 25 irrigations / year (middle interval) was given to second treatment irrigation at10 days intervals in Summer, at 15 days intervals in Spring and Autumn and at 21 days intervals in Winter seasons and $200 \mathrm{Kg} \mathrm{N} /$ fed. conversely the least values of sucrose percentage (12.01 and $12.02 \%)$ were obtained from applying 18 irrigations / year (large interval) was given to first treatment irrigation at 15 days intervals in Summer, at 20 days intervals in Spring and Autumn and at 30 days intervals in Winter seasons and $140 \mathrm{Kg} \mathrm{N} /$ fed. in the $1^{\text {st }}$ and $2^{\text {nd }}$ seasons, respectively.

In conclusion, the study demonstrates a general positive relationship between increasing $\mathrm{N}$ fertilizer up to $(200 \mathrm{~kg} / \mathrm{fed})$, middle irrigation interval on stalk and sugar yields besides juice quality of G2006-77 sugarcane variety under Alexandria conditions. Results further revealed that excess of $\mathrm{N}(260 \mathrm{~kg} / \mathrm{fed})$, short and long interval of irrigation are decreasing the sugar quality

\section{REFERENCES}

Ali, S.A. (1996). Response of varying nitrogen and soil moisture regimes on sugarcane Crop.Bharatiya Sugar. 22(4):7-10.

Ankerman,D. and L.Large. (1974).Soil and plant analysis,ASL Agricultural laboratories.Inc.New York, USA.

A.O.A.C.(1985). Official Methods of Analysis of the Association of Official Agriculture Chemists. $14^{\text {th }}$ ed. Benjumin Franklin Station,Washington DC. 20044,: 494-510.

Azzazy, N.B., A.M.A. El-Shafai and I.H. El-Geddawy, (2000). Yield and quality of stubble cane as affected by irrigation, nitrogen fertilization, and varieties. Egyptian J. of Agric. Res., 78(4): 1615-1624.

Azzazy, N.B. and I.H. El-Geddawy, (2003). Effect of nitrogen fertilization on yield and quality of some sugarcane varieties under developed surface irrigation system. Egypt j. Agric. Res., 81(3): 1137-1147

Bahrani, M. J. ; M. Shomeili; SH. Zande and A. K. Haghighi. (2009). Sugarcane responses to irrigation and nitrogen in Subtropical. Iran Agric. Res., 27(1): 17-26.
Barbosa, F.D.B. ; R.D. Coelho; R. Maschio; C.J.G. Lima and E.M. Silva. (2014). Drought resistance of sugarcane crop for different levels of water availability in the soil., Eng.Agríc. 34 (2): 1-25.

Bekheet,M.A.(2006). Effect of irrigation and potassium fertilization on yield and quality of two sugarcane varieties. Assiut J Agric. Sci.,37 (1)1:19.

Bhatti, H.M. ; M. H. Ullah; M.R. Khan and M.R. Gill, (1986). Consumptive use of water for sugarcane crop. J. Agric. Res., 24(1): 59-60.

El-Geddawy, I.H.; M.A, M, Rizk; M.G.A. Taha and M.S.H.Osman (2003). Effect of nitrogen fertilization on yield and yield components of sugarcane. Egypt. J.Agric. Res.,81(4)1657-1669.

El-Geddawy, I.H.; M.S.Rady; H.A.Dawwam; F.A.Hendawy and R.A.M.Abo El-Ghait.(2005) Response of some sugarcane varieties to nitrogen and potassium application. Egypt J. Agric. Res., 83(2): 693-716.

El-Geddawy, I.H.; S.E.Shsfshak; G,Y.M.Hammam and A.M.A.El-Shafai (2004). Irrigation regimes and nitrogen fertilization effect on sugarcane. yield and its components. Egypt. J.Agric. Res., 82(4)1721-1732.

El-Shafai,A.M.A.(1996). Water requirements of sugarcane under different levels of nitrogen fertilization. Ph.D. Thesis,Agron. Dept. Fac, Agric.. Moshtohor, Zagazig Univ.Egypt.

Gary, H.; P. Mc.Guire and G. Kingston .(2000). Irrigation of Sugarcane. Manual-Ch 196 (20): 10 -16.

Gomaa, A.M.E.G. (2000). Physiological studies on the response of sugarcane to irrigation. Ph.D Thesis, ,Agron. Dept. Fac, Agric.Al-Azhar,Univ., Egypt.

Immbaby, M.M.M.(2003). Evaluation of some sugarcane varieties under different irrigation treatments. Ph.D Thesis, Agron. Dept. Fac, Agric.El-Minia,Univ., Egypt..

Inman-Bamber N.G. and D.M. Smith (2005). Water relations in sugarcane and response to water deficits. Field Crops Res. 92:185-202

Maher, M.M.I. (2003). Evaluation of some sugar cane varieties under different irrigation treatments. Ph.D. Thesis,Agron.Dept., Fac.Agric., Minia Univ. Egypt.

Nassar, A.M.; K.S.El-Sagheir and B.S.H.Ramadan. (2005). Effect of nitrogen levels on yield and juice quality of some sugarcane varieties. Egyptian J. Agric. Res., 83(2): 681-692. 
Qureshi, M. E.; M.K. Wegener; S.R. Harison, and K.L. Bristow (2001). Economic Evaluation of Irrigation System for Sugarcane in the Burdekin delta in North Queensland, Australia. Water Resource Management, WIT Press, Boston:47-57.

Singh,R.P.and P.P.Singh (1998). Quality of juice and commercial sugar cane as influenced by crop cane. Indian Sugar, 34(1):21-28.

Steel R.G.D. and J.H.Torrie. (1981). Principles and Procedures of Statistic, Abiometrical approach. $2^{\text {nd }}$ ed.by Mc Graw -Hill International Book Company, Singapore, 633.

Taha, E.M.; A.Z. Ahmed and K.S. El-Sagheir, (2003). Response of four sugarcane varieties to potassium fertilizer. Egyptian J. Agric. Res. 81(1): 151-160.
Wiedenfeld, R.P and J. Enciso (2008), Sugarcane Responses to Irrigation and Nitrogen in Semiarid South Texas., Agronomy J. (100), Issue 3: 665- 671.

Yadav, R.L.; R. Kumar and R. S. Verma. (1990). Effect of nitrogen applied through new carriers on yield and quality of sugarcane. J. Agric. Sci. Cambridge (114): 225-230.

Yahaya, M.S.; A.M. Falaki; E.B. Amans and L D. Busari (2010) Sugarcane yield and quality as influenced by nitrogen rates and irrigation frequency . Nigerian J. Res. and Pro., (17): 2: 1-10.

Yousef, M.A., E.M. Taha, and A.Z. Ahmad. (2000). Influence of some cultural practices on yield and yield components of some sugarcane varieties. Egyptian J. Agric. Res., 78 (5): 1995-2008. 


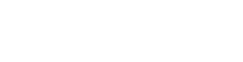

\section{تأثيرقام الري وستتوبلت النسميد النترجيني علي المحصط ومكوناله لهصب السكر}

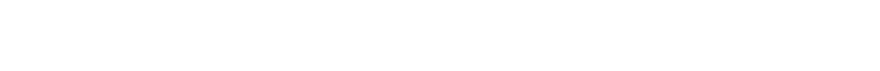

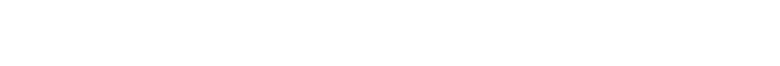

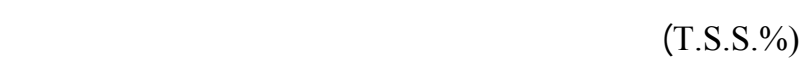

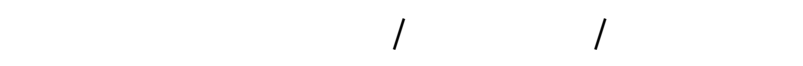

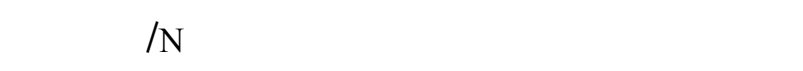

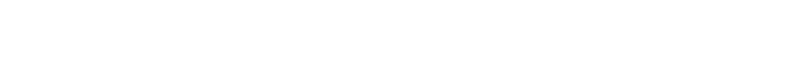

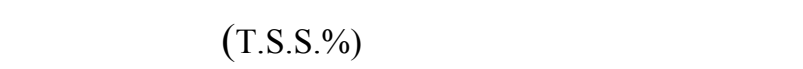
والنبة المئوية للسكروز.

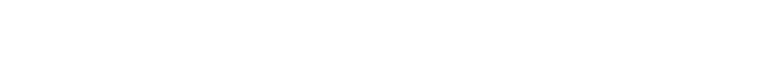
فترات الري ومستويت النيتروجين المدروسة فيما يتعل ق بصفل:طولسلق القصب وتطره ومحصول للسكرو نسبة

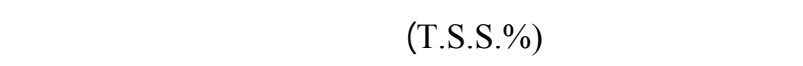

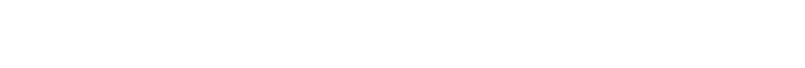

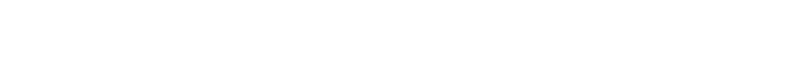

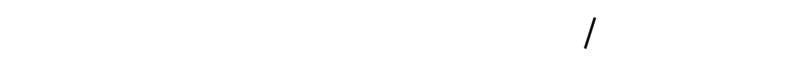
ن لفدان (10.10 - 10.07 \% في الموسمين بالترتيب. ولستنادا إلى النتائج التي مم الحصول عليها بإن اعل مي

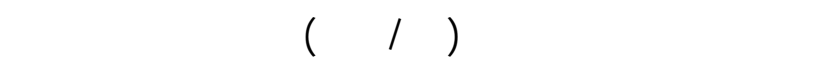

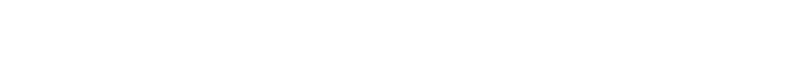

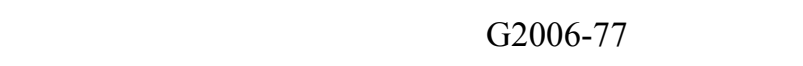

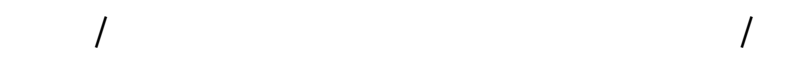
تمتظظورف الاسكندرية.
أقيمت تجربتان حقليت لن خ لالل موس مع الزراء ـة

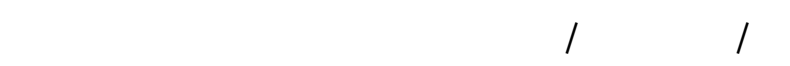

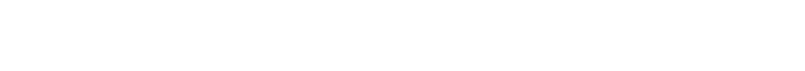
درلسة تأثير ظم الرى ومستويت التسميد النتروجيني علي محصول ومكوناته لقصب السكر وجودة العصير. split -plot وقد لأستخدم فى التجربة تصميم التطع المنشفيانه design

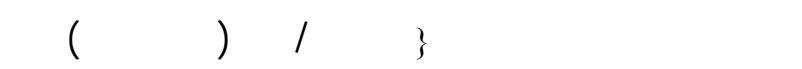

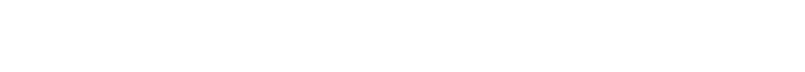

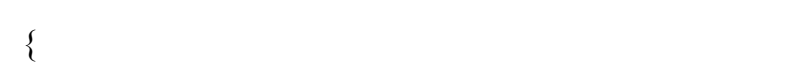

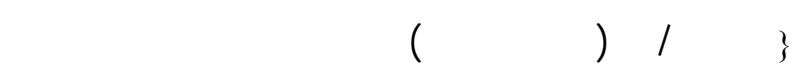

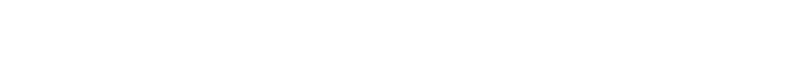

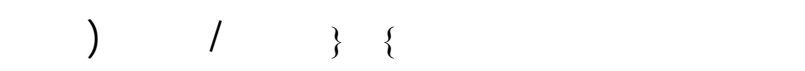

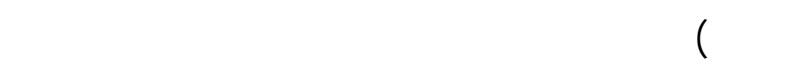

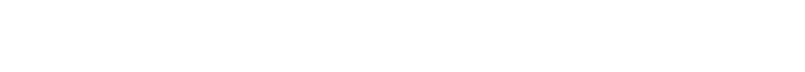

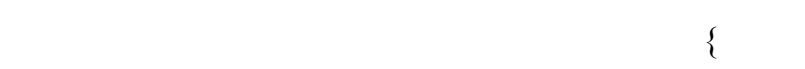

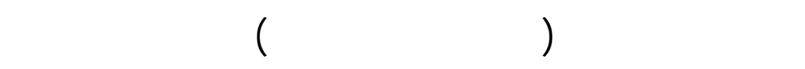

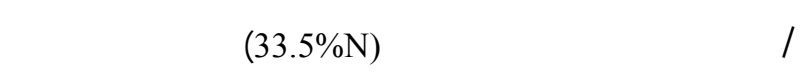
أهم نتائج هذه الدرلسة فيما يله:

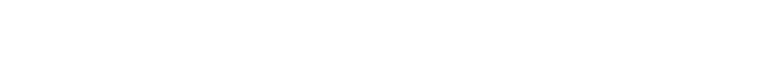

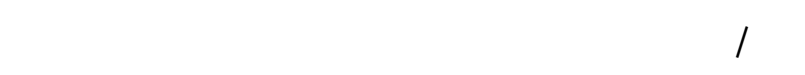

